\title{
$\alpha$-Lipoic Acid Inhibits Helicobacter pylori-Induced Oncogene Expression and Hyperproliferation by Suppressing the Activation of NADPH Oxidase in Gastric Epithelial Cells
}

\author{
Eunyoung Byun, ${ }^{1}$ Joo Weon Lim, ${ }^{1}$ Jung Mogg Kim, ${ }^{2}$ and Hyeyoung Kim ${ }^{1}$ \\ ${ }^{1}$ Department of Food and Nutrition, Brain Korea 21 PLUS Project, College of Human Ecology, Yonsei University, \\ Seoul 120-749, Republic of Korea \\ ${ }^{2}$ Department of Microbiology, Hanyang University College of Medicine, Seoul 133-791, Republic of Korea
}

Correspondence should be addressed to Hyeyoung Kim; kim626@yonsei.ac.kr

Received 17 June 2014; Revised 28 July 2014; Accepted 1 August 2014; Published 19 August 2014

Academic Editor: Yung-Hsiang Chen

Copyright (C) 2014 Eunyoung Byun et al. This is an open access article distributed under the Creative Commons Attribution License, which permits unrestricted use, distribution, and reproduction in any medium, provided the original work is properly cited.

\begin{abstract}
Hyperproliferation and oncogene expression are observed in the mucosa of Helicobacter pylori- (H. pylori-) infected patients with gastritis or adenocarcinoma. Expression of oncogenes such as $\beta$-catenin and c-myc is related to oxidative stress. $\alpha$-Lipoic acid $(\alpha$ LA), a naturally occurring thiol compound, acts as an antioxidant and has an anticancer effect. The aim of this study is to investigate the effect of $\alpha$-LA on $H$. pylori-induced hyperproliferation and oncogene expression in gastric epithelial AGS cells by determining cell proliferation (viable cell numbers, thymidine incorporation), levels of reactive oxygen species (ROS), NADPH oxidase activation (enzyme activity, subcellular levels of NADPH oxidase subunits), activation of redox-sensitive transcription factors (NF- $\kappa \mathrm{B}, \mathrm{AP}-1)$, expression of oncogenes ( $\beta$-catenin, $\mathrm{c}$-myc), and nuclear localization of $\beta$-catenin. Furthermore, we examined whether NADPH oxidase mediates oncogene expression and hyperproliferation in $H$. pylori-infected AGS cells using treatment of diphenyleneiodonium (DPI), an inhibitor of NADPH oxidase. As a result, $\alpha$-LA inhibited the activation of NADPH oxidase and, thus, reduced ROS production, resulting in inhibition on activation of NF- $\kappa \mathrm{B}$ and AP-1, induction of oncogenes, nuclear translocation of $\beta$-catenin, and hyperproliferation in $H$. pylori-infected AGS cells. DPI inhibited $H$. pylori-induced activation of NF- $\kappa$ B and AP-1, oncogene expression and hyperproliferation by reducing ROS levels in AGS cells. In conclusion, we propose that inhibiting NADPH oxidase by $\alpha$-LA could prevent oncogene expression and hyperproliferation occurring in $H$. pylori-infected gastric epithelial cells.
\end{abstract}

\section{Introduction}

Epidemiologic studies showed that Helicobacter pylori $(H$. pylori) infection increased the incidence of gastric cancer up to 6-fold [1-4]. The key features of developing gastric cancer are hyperproliferation and oncogene expression of gastric epithelial cells. Oncogenes such as $\beta$-catenin and c-myc stimulate cell proliferation and promote malignant changes. $H$. pylori infection is associated with hyperproliferation of gastric epithelial cells in humans and experimental animals [5-7]. Nuclear level of $\beta$-catenin was increased by $H$. pylori infection in gastric epithelial cells $[6,7]$. However, the mechanisms by which $H$. pylori infection promotes epithelial hyperproliferation remain poorly understood. $\beta$-catenin has a key role in inflammation and cancer development [8]. Cytosolic and nuclear levels of $\beta$-catenin are tightly regulated by signaling molecules in the cells [9]. Upon activation, $\beta$-catenin is stabilized and translocated into the nucleus. In the nucleus, $\beta$-catenin binds to TCF family and serves as a transcriptional regulator [10, 11]. Recent study showed that $H$. pylori infection stimulates release of $\beta$-catenin which in turn is translocated into nucleus [12]. Nuclear translocation of $\beta$-catenin and cell proliferation have been related to c-myc in $H$. pylori-infected cells [13]. c-myc is one of the genes regulated by $\beta$-catenin, whose expression is directly activated by $\beta$-catenin/TCF in colon cancers [14]. As a protooncogene, c-myc stimulates the expression of target genes, which plays important roles in uncontrolled 
cell proliferation by binding to consensus $5^{\prime}$-CACGTG$3^{\prime}$ nucleotide sequences in the region of these genes and behaving as a transcriptional activator [15].

Previously, we found that reactive oxygen species (ROS) were produced to induce IL-8 expression in $H$. pylori-infected gastric epithelial cells, which may contribute to neutrophil recruitment to the infected tissues [16]. Several studies suggest that nicotinamide adenine dinucleotide phosphate (NADPH) oxidase is involved in ROS production of $H$. pylori-infected gastric mucosa in humans and mice [1719]. For the activation of NADPH oxidase, the assembly of membrane-integrated cytochrome b558 (a heterodimer formed by gp91 ${ }^{\text {phox }}$ and $\mathrm{p} 22^{\text {phox }}$ ) and cytosolic components $\mathrm{p} 47^{\text {phox }}, \mathrm{p} 67^{\text {phox }}$, and GTPase Rac are necessary. Electron transfer occurs from NADPH to molecular $\mathrm{O}_{2}{ }^{-}$which is spontaneously converted to $\mathrm{H}_{2} \mathrm{O}_{2}$ [20]. Therefore, membrane translocation of cytosolic subunits is a main switch in NADPH oxidase activation.

Nollet et al. [21] reported that there are binding sites for redox-sensitive transcription factors NF- $\kappa \mathrm{B}$ and AP-1in the promoter region of $\beta$-catenin. NF- $\kappa \mathrm{B}, \mathrm{AP}-1$, and $\beta$ catenin signaling contributed to survival of TNF- $\alpha$-treated hepatocytes in vitro [22]. Since NF- $\kappa \mathrm{B}$ and AP-1 are activated by ROS, NADPH oxidase-generated ROS may induce expression of oncogenes ( $\beta$-catenin, $c$-myc) by activating NF- $\kappa \mathrm{B}$ and AP-1 in $H$. pylori-infected gastric epithelial cells.

$\alpha$-Lipoic acid ( $\alpha$-LA), also known as thioctic acid, is a naturally occurring antioxidant that is synthesized in small amounts in plants and animals including humans [23]. $\alpha$-LA is considered as an ideal antioxidant since it possesses many beneficial characteristics, including free-radical quenching activity, recycling other antioxidants, and suppressive effects on redox-sensitive gene expression [24]. $\alpha$-LA inhibited NF$\kappa \mathrm{B}$ activation and protected oxidative cell injury [25]. Growth inhibitory effect of $\alpha$-LA was shown in ovarian epithelial cancer cells [26]. Wenzel et al. [27] demonstrated that $\alpha$ LA has carcinostatic effects in cancer patients by increasing glutathione and reducing oxidative stress in cancer cells.

The purpose of the present study is to investigate the effect of $\alpha$-LA on hyperproliferation and oncogene expression in $H$. pylori-infected gastric epithelial cells by determining cell proliferation (viable cell numbers, thymidine incorporation), ROS levels, NADPH oxidase activation (enzyme activity, subcellular levels of NADPH oxidase subunits), activation of redox-sensitive transcription factors (NF- $\kappa \mathrm{B}, \mathrm{AP}-1)$, expression of oncogenes ( $\beta$-catenin, $c$-myc), and nuclear localization of $\beta$-catenin. Furthermore, we examined the effect of diphenyleneiodonium (DPI), an inhibitor of NADPH oxidase, on oncogene expression and hyperproliferation in H. pylori-infected AGS cells to elucidate whether NADPH oxidase mediates $H$. pylori-induced proliferation.

\section{Materials and Methods}

2.1. Bacterial Strain. H. pylori, strain NCTC 11637, was obtained from the American Type Culture Collection (Rockville, MD). The genotype of this bacterium is cag $A^{+}$and $v a c A^{+}$and was inoculated on chocolate agar plates (Becton
Dickinson Microbiology Systems, Cockeysville, MD, USA) at $37^{\circ} \mathrm{C}$ under microaerophilic conditions using an anaerobic chamber (BBL Campy Pouch System, Becton Dickinson Microbiology Systems) [28].

2.2. Cell Line and Culture H. pylori Infection. A human gastric epithelial cell line AGS (gastric adenocarcinoma, ATCC CRL 1739) was purchased from the American Type Culture Collection. The cells were grown in complete medium, consisting of RPMI 1640 medium supplemented with $10 \%$ fetal bovine serum, $2 \mathrm{mM}$ glutamine, $100 \mathrm{U} / \mathrm{mL}$ penicillin, and $100 \mu \mathrm{g} / \mathrm{mL}$ streptomycin (Sigma, St. Louis, MO, USA) [28]. AGS cells were seeded and cultured overnight to reach $80 \%$ confluency. Before $H$. pylori infection, the cells were washed with antibiotic-free culture medium. Whole $H$. pylori was harvested and suspended in antibiotic-free RPMI 1640 medium supplemented with $10 \%$ fetal bovine serum and treated to AGS cells.

2.3. Experimental Protocol. Prior to the experiment on $\alpha$-LA, the cells were cultured at bacterium/cell ratio of $10: 1,20: 1$, and $50: 1$ to determine the appropriate density of $H$. pylori to the cells for cell proliferation, thymidine incorporation (at $8 \mathrm{~h}$ ), oncogene expression (at $24 \mathrm{~h}$ ), ROS production (at $30 \mathrm{~min}$ ), and NADPH oxidase activity (at $30 \mathrm{~min}$ ). At bacterium/cell ratio of $50: 1$, cells were cultured for $24 \mathrm{~h}$ to determine oncogene expression at mRNA and protein levels. For the effect of $\alpha$-LA or DPI, the cells were cultured at bacterium/cell ratio of $50: 1 . \alpha$-LA and DPI were purchased from Sigma-Aldrich (St. Louis, MO, USA). $\alpha$-LA was dissolved in ethanol while DPI was dissolved in dimethylsulfoxide (DMSO). The cells were pretreated with $\alpha$-LA $(10 \mu \mathrm{M}, 20 \mu \mathrm{M})$ or DPI $(1 \mu \mathrm{M}, 2 \mu \mathrm{M})$ for $2 \mathrm{~h}$ before $H$. pylori infection. Cell proliferation, thymidine incorporation (at $8 \mathrm{~h}$ ), oncogene expression (at $24 \mathrm{~h}$ ), ROS production (at $30 \mathrm{~min}$ ), activity and cellular localization of NADPH oxidase (at $30 \mathrm{~min}$ ), and activation of NF- $\kappa \mathrm{B}$ and $\mathrm{AP}-1$ (at $1 \mathrm{~h}$ ) were determined. The control group received ethanol or DMSO instead of $\alpha$-LA or DPI. Total volume of ethanol or DMSO treated to AGS cells was less than $0.5 \%$.

2.4. Cell Proliferation. Cell proliferation was determined by viable cell numbers. Cell numbers were determined by direct counting with a hemocytometer using a trypan blue exclusion test $(0.2 \%$ trypan blue $)$.

\section{5. $\left[{ }^{3} \mathrm{H}\right]$ Thymidine Incorporation. AGS cells $\left(1 \times 10^{4} /\right.$ well $)$} were pretreated with $\alpha$-LA for $2 \mathrm{~h}$ and cultured in the presence or absence of $H$. pylori in a 24-well culture plate. After $24 \mathrm{~h}$-culture, $1 \mu \mathrm{Ci} / \mathrm{mL}\left[{ }^{3} \mathrm{H}\right]$ thymidine (Amersham Biosciences) was added to the cells, and the cells were cultured for an additional $8 \mathrm{~h}$. The cells were then washed twice with phosphate-buffered saline, incubated in $10 \%$ trichloroacetic acid for $30 \mathrm{~min}$, and incubated with a solution consisting of $0.3 \mathrm{MNaOH}$ and $1 \%$ SDS for $1 \mathrm{~h}$. The cells were extracted with vortexing and the radioactivity was determined in a Packard liquid scintillation counter (Packard Instrument Co. Inc., Grove, IL, USA). The relative amount 
of $\left[{ }^{3} \mathrm{H}\right]$ thymidine incorporation, which reflects the extent of DNA synthesis, is expressed as a percentage of that shown in the cells cultured in the absence of $H$. pylori. The amount of $\left[{ }^{3} \mathrm{H}\right]$ thymidine incorporation of the cells cultured in the absence of $H$. pylori is considered as $100 \%$ [29].

2.6. Real-Time PCR Analysis for $\beta$-Catenin and $c$-myc. Total RNA was isolated by TRI reagent (RNA/DNA/Protein isolation reagent, Molecular Research Center, Inc., Cincinnati, $\mathrm{OH}, \mathrm{USA})$. Total RNA was converted into cDNA by reverse transcription process using a random hexamer and $\mathrm{M}$ MLV reverse transcriptase (Promega, Madison, WI, USA) with conditions at $23^{\circ} \mathrm{C}$ for $10 \mathrm{~min}, 37^{\circ} \mathrm{C}$ for $60 \mathrm{~min}$, and $95^{\circ} \mathrm{C}$ for $5 \mathrm{~min}$. The cDNA was used for real-time PCR with specific primers for $\beta$-catenin, c-myc, and $\beta$-actin. Sequences of $\beta$-catenin primers were $5^{\prime}$-GTTCGTGCACATCAGGATAC- $3^{\prime}$ (forward primer) and $5^{\prime}$-CGATAGCTAGGATCATCCTG-3' (reverse primer), giving a 529 bp PCR product. Sequences of c-myc primers were $5^{\prime}$-GGACGACGAGACCTTCATCAA-3 ${ }^{\prime}$ (forward primer) and $5^{\prime}$ CCAGCTTCTCTGAGACGAGCTT-3' (reverse primer), giving a $92 \mathrm{bp}$ PCR product. For $\beta$-actin, the forward primer was $5^{\prime}$-ACCAACTGGGACGACATGGAG- $3^{\prime}$ and the reverse primer was $5^{\prime}$-GTGAGGATCTTCATGAGGTAGTC-3', giving a $353 \mathrm{bp}$ PCR product. For PCR amplification, the cDNA was amplified by 40 cycles, denaturation at $95^{\circ} \mathrm{C}$ for $15 \mathrm{sec}$, annealing at $60^{\circ} \mathrm{C}$ for $15 \mathrm{sec}$, and extension at $72^{\circ} \mathrm{C}$ for $45 \mathrm{sec}$. $\beta$-Actin gene was amplified in the same reaction to serve as the reference gene.

2.7. Western Blot Analysis. Whole cell extracts, membrane extracts, cytosolic extracts, and nuclear extracts were prepared as described previously [28]. 100-200 $\mu$ g of protein was loaded per lane, separated by $8-12 \%$ SDS-polyacrylamide gel electrophoresis under reducing conditions, and transferred onto nitrocellulose membranes (Amersham, Inc., Arlington Heights, IL, USA) by electroblotting. The transfer of protein was verified using reversible staining with Ponceau S. Membranes which were blocked using 3\% nonfat dry milk. The proteins were detected with antibodies for $\beta$-catenin, c-myc, p47, p67, NOX-1, aldolase A, histone H1, and actin (all from Santa Cruz Biotechnology) dilution in TBS-T containing $3 \%$ dry milk, and incubated overnight at $4^{\circ} \mathrm{C}$, followed by secondary antibodies (anti-goat, anti-mouse, or anti-rabbit) conjugated to horseradish peroxidase and determination of enhanced chemiluminescence (Amersham) using exposure to BioMax MR film (Kodak, Rochester, NY) [30].

2.8. Measurement of ROS Levels. After $30 \mathrm{~min}$ of $H$. pylori infection, the cells were loaded with $10 \mu \mathrm{M}$ dichlorofluorescein diacetate (DCF-DA; Molecular Probes, Eugene, OR, USA) for $30 \mathrm{~min}$, washed, and scraped off into $1 \mathrm{~mL}$ of PBS. The DCF fluorescence was measured (excitation at $495 \mathrm{~nm}$ and emission at $535 \mathrm{~nm}$ ) with a Vctior3 multilabel counter (PerkinElmer Life and Analytical Sciences, Boston, MA, USA). ROS trapped into the cells were expressed as therelative increase [31].
2.9. Electrophoretic Mobility Shift Assay (EMSA). A NF- $\kappa \mathrm{B}$ gel shift oligonucleotide (AGTTGAGGGGACTTTCCCAGGC) and a AP-1 gel-shift oligonucleotide (CGCTTGATA GTCAGCCGGAA) (all from Promega, Madison, WI, USA) were labeled with $\left[{ }^{32} \mathrm{P}\right]$ dATP (Amersham) using the T4 polynucleotide kinase (GIBCO, Grand Island, NY, USA). The end-labeled probe was purified from an unincorporated $\left[{ }^{32} \mathrm{P}\right]$ dATP using a Bio-Rad purification column (Bio-Rad Laboratories) and recovered in Tris-EDTA buffer (TE). Nuclear extracts $(3 \mu \mathrm{g})$ were incubated with the buffer containing

${ }^{32} \mathrm{P}$-labeled NF- $\kappa \mathrm{B}$ or AP-1 consensus oligonucleotide for $30 \mathrm{~min}$ and subjected to electrophoretic separation on a nondenaturing acrylamide gel. The gels were dried at $80^{\circ} \mathrm{C}$ for $2 \mathrm{~h}$ and exposed to a radiography film for $6-18 \mathrm{~h}$ at $-70^{\circ} \mathrm{C}$ with intensifying screens [28].

2.10. Determination of NADPH Oxidase Activity. The assay was performed in $50 \mathrm{mM}$ Tris-Mes buffer, $\mathrm{pH}$ 7.0, containing $2 \mathrm{mM}$ KCN, $10 \mu \mathrm{M}$ lucigenin and $100 \mu \mathrm{M}$ NADPH as the substrate. The reaction was started by addition of membrane extracts containing $10 \mu \mathrm{g}$ protein. The photon emission was measured every $15 \mathrm{sec}$ for $5 \mathrm{~min}$ in a microtiterplate luminometer (Micro-Lumat LB 96 V luminometer, Berthold, $\mathrm{NH}$, USA). NADPH oxidase activity was also monitored by addition of cytosolic extracts to the reaction mixture as a negative control [32].

2.11. Immunofluorescence Staining for $\beta$-Catenin. The cells were cultured in the presence or absence of $H$. pylori for $24 \mathrm{~h}$ on Lab-TeK chamber slide glasses and fixed with cold $100 \%$ methanol. The fixed cells were blocked for $30 \mathrm{~min}$ in a blocking solution and then incubated for $1 \mathrm{~h}$ with primary antibody for $\beta$-catenin. After washing with PBS, the cells were reacted with FITC-labeled goat anti-mouse IgG antibody for $1 \mathrm{~h}$. After removal of the secondary antibodies, the cells were washed with PBS and covered with the antifade medium Vectashield containing $4^{\prime}$,6-diamidino2-phenylindole (DAPI). The preparations were stored for $1 \mathrm{~h}$ to allow saturation with DAPI. The cells stained with FITC-labeled antibody for $\beta$-catenin were examined with a laser-scanning confocal microscope (LSM510, Carl Zeiss Inc., Oberkochen, Germany) [33].

2.12. Statistical Analysis. Results are expressed as mean \pm S.E.M. of four separate experiments. Analysis of variance (ANOVA), followed by Newman-Keul's post hoc test was used for statistical analysis. $P<0.05$ was considered statistically significant.

\section{Results}

3.1. H. pylori Induces Hyperproliferation and Expression of $\beta$-Catenin and c-myc in AGS Cells. During $72 \mathrm{~h}$-culture, $H$. pylori increased cell numbers as compared to the cells without infection (Figure 1(a)). With cell proliferation, $H$. pylori elicited an increase in thymidine incorporation, an index of DNA synthesis at $24 \mathrm{~h}$-culture (Figure 1(b)). $H$. pylori-induced proliferation, activation of NADPH oxidase, 


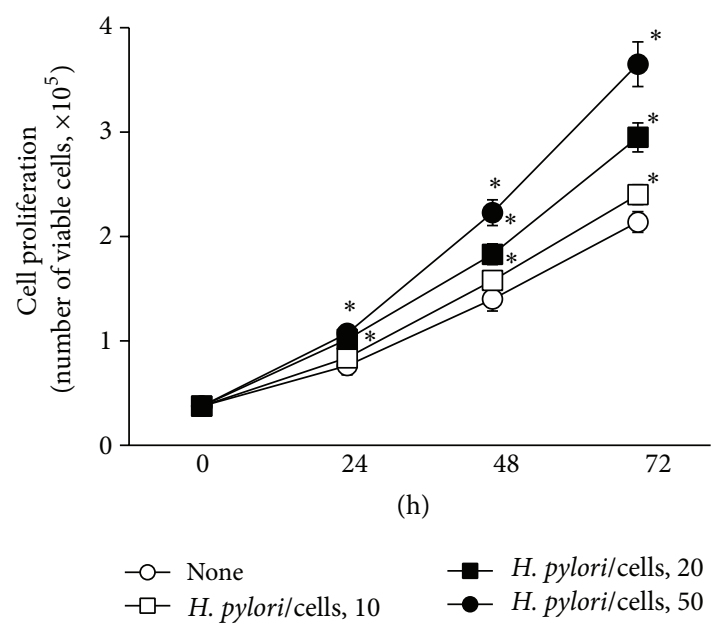

(a)

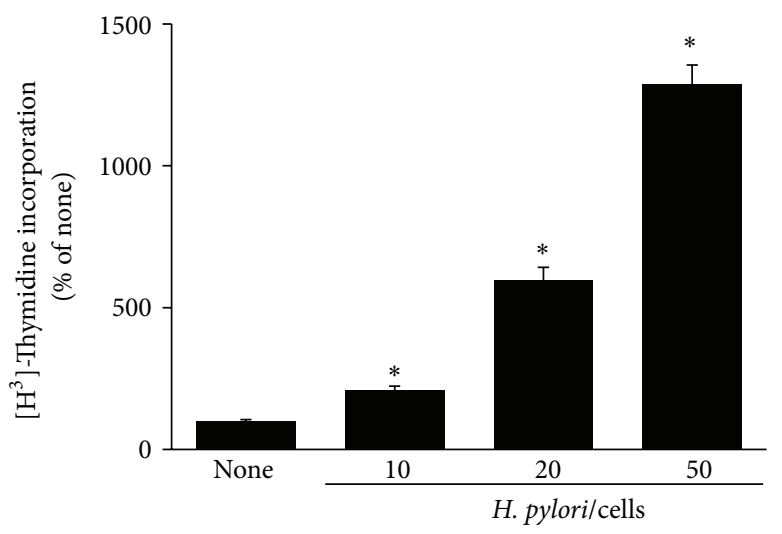

(b)

FIGURE 1: Cell proliferation of AGS cells infected with $H$. pylori. AGS cells were cultured in the presence or absence of $H$. pylori (at bacterium/cell ratio of $10,20,50: 1)$. Cell proliferation was assessed by viable cell numbers and $\left[{ }^{3} \mathrm{H}\right]$ thymidine incorporation. (a) Viable cell numbers were determined by trypan blue exclusion assay at the indicated time period. (b) The cells were treated with $\left[{ }^{3} \mathrm{H}\right]$ thymidine at $24 \mathrm{~h}$ after $H$. pylori infection and incubated for $8 \mathrm{~h}$. The amount of $\left[{ }^{3} \mathrm{H}\right]$ thymidine incorporation of AGS cells cultured in the absence of $H$. pylori is considered as $100 \% .{ }^{*} \mathrm{P}<0.05$ versus corresponding none (the cells cultured in the absence of $H$. pylori).

ROS production, and oncogene expression were highest at bacterium/cell ratio of $50: 1$ as compared to those at $20: 1$ and $10: 1$ (Figures 1(b), 2(a), 2(b), 2(d), and 2(f)). The expression levels of $\beta$-catenin and $c$-myc were increased by $H$. pylori infection with culture time at bacterium/cell ratio of $50: 1$ (Figures 2(c) and 2(e)).

3.2. $\alpha$-LA Suppresses $H$. pylori-Induced Hyperproliferation, Increase in ROS Levels, and NADPH Oxidase Activation in AGS Cells. $\alpha$-LA inhibited $H$. pylori-induced cell proliferation (determined by viable cell numbers during $72 \mathrm{~h}$ culture) and DNA synthesis (at $8 \mathrm{~h}$ culture) in AGS cells (Figures 3(a) and 3(b)). As shown in Figure 4(a), H. pylori-induced increase in ROS levels was reduced by $\alpha$-LA treatment. Inhibitory effect of $\alpha$-LA on $H$. pylori-induced cell proliferation and ROS production was higher at $20 \mu \mathrm{M}$ than $10 \mu \mathrm{M}$ (Figures 3 and $4(\mathrm{a})$ ).

To further ensure the effect of $\alpha$-LA on $H$. pylori-induced activation of NADPH oxidase, enzyme activity and subcellular levels of NADPH oxidase subunits were determined by lucigenin assay and Western blot analysis at $30 \mathrm{~min}$ culture (Figures 4(b) and 4(c)). H. pylori-induced increase in NADPH oxidase activity was suppressed by $\alpha$-LA. For NADPH oxidase activation, the translocation of cytosolic subunits $\mathrm{p} 47^{\text {phox }}$ and $\mathrm{p} 67^{\text {phox }}$ to the membrane is required. As shown in Figure 4(c), H. pylori-induced translocation of cytosolic subunits $\mathrm{p} 47^{\text {phox }}$ and $\mathrm{p} 67^{\text {phox }}$ to membrane was inhibited by $\alpha$-LA in AGS cells. Aldolase A and Noxl as indices for cytosol and membrane, were not changed by $H$. pylori infection or treatment of $\alpha$-LA.

3.3. $\alpha$-LA Suppresses H. pylori-Induced Expression of Oncogenes, Activation of NF- $\kappa B$ and AP-1, and Nuclear Translocation of $\beta$-Catenin in AGS Cells. $\alpha$-LA inhibited H. pyloriinduced expressions of $\beta$-catenin and c-myc in AGS cells at $24 \mathrm{~h}$ culture (Figures 5(a) and 5(b)). Furthermore, $\alpha$-LA showed an inhibitory effect on $H$. pylori-induced activation of NF- $\kappa \mathrm{B}$ and AP-1 at $1 \mathrm{~h}$ culture (Figure 5(c)). Inhibitory effect of $\alpha$-LA on $H$. pylori-induced oncogene expression and activation of NF- $\kappa \mathrm{B}$ and AP- 1 was higher at $20 \mu \mathrm{M}$ than $10 \mu \mathrm{M}$ of $\alpha$-LA.

To determine the effect of $\alpha$-LA on activation of $\beta$ catenin, we observed both cytosolic and nuclear levels of $\beta$ catenin in $H$. pylori-infected cells cultured in the presence or absence of $\alpha$-LA (Figure 6(a)). Nuclear level of $\beta$-catenin was increased, but cytosolic level of $\beta$-catenin was decreased in $H$. pylori-infected cells. Aldolase A and histone $\mathrm{H1}$, as indices for cytosol and nucleus, were not changed by $H$. pylori infection. $H$. pylori-induced activation of $\beta$-catenin was suppressed by treatment of $\alpha$-LA in a dose-dependent manner. To confirm the inhibitory effect of $\alpha$-LA on activation of $\beta$-catenin in $H$. pylori-infected AGS cells, nuclear localization of $\beta$ catenin was determined by immunofluorescence staining of $\beta$-catenin (Figure 6(b)). H. pylori induced translocation of $\beta$-catenin from cytosol to nucleus, which was inhibited by treatment of $\alpha$-LA in AGS cells.

3.4. DPI Inhibits H. pylori-Induced Increase in ROS Levels, Hyperproliferation, Expression of Oncogenes, and Activation of NF- $\kappa B$ and AP-1 in AGS Cells. As shown in Figure 7(a), $H$. pylori-induced increase in ROS levels was reduced by DPI treatment. DPI inhibited $H$. pylori-induced cell proliferation (determined by viable cell numbers) and DNA synthesis in AGS cells (Figures 7(b) and 7(c)). DPI itself did not affect cell viability during $72 \mathrm{~h}$ culture (Figure 7(b)). DPI inhibited $H$. pylori-induced expressions of $\beta$-catenin and c-myc in AGS cells at $24 \mathrm{~h}$ culture (Figures $8(\mathrm{a})$ and $8(\mathrm{~b})$ ). In addition, DPI showed an inhibitory effect on $H$. pylori-induced activation of $\mathrm{NF}-\kappa \mathrm{B}$ and AP- 1 at $1 \mathrm{~h}$ culture (Figure $8(\mathrm{c})$ ). Inhibitory effect 


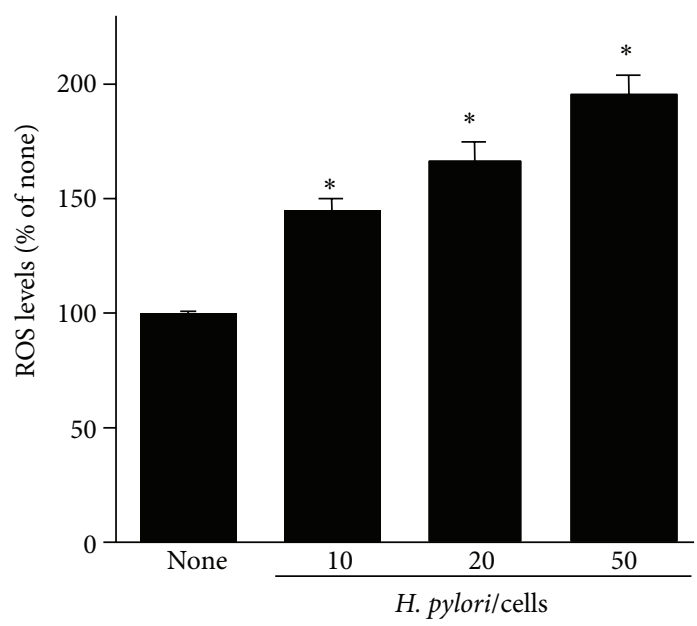

(a)

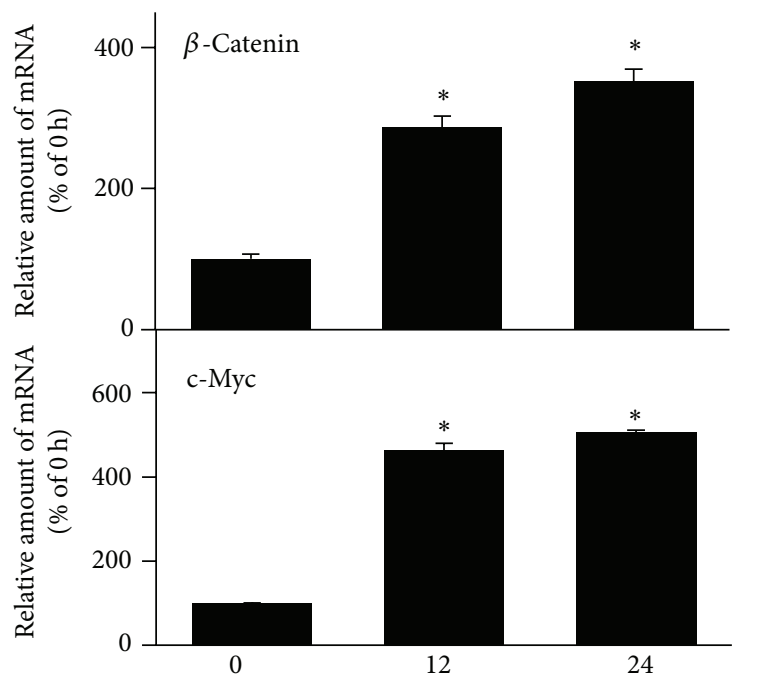

(h)

(c)

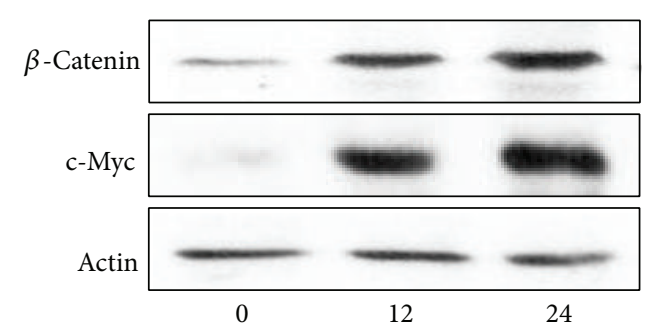

(h)

(e)

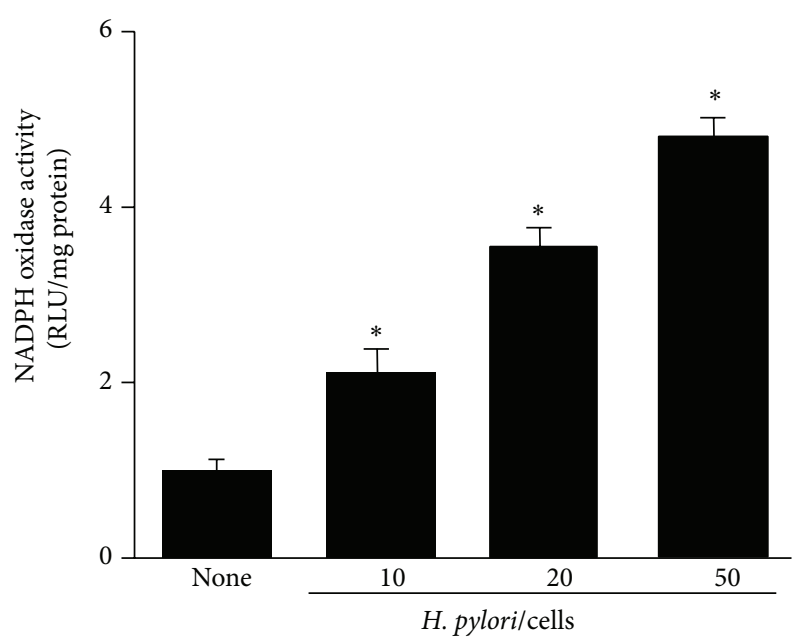

(b)

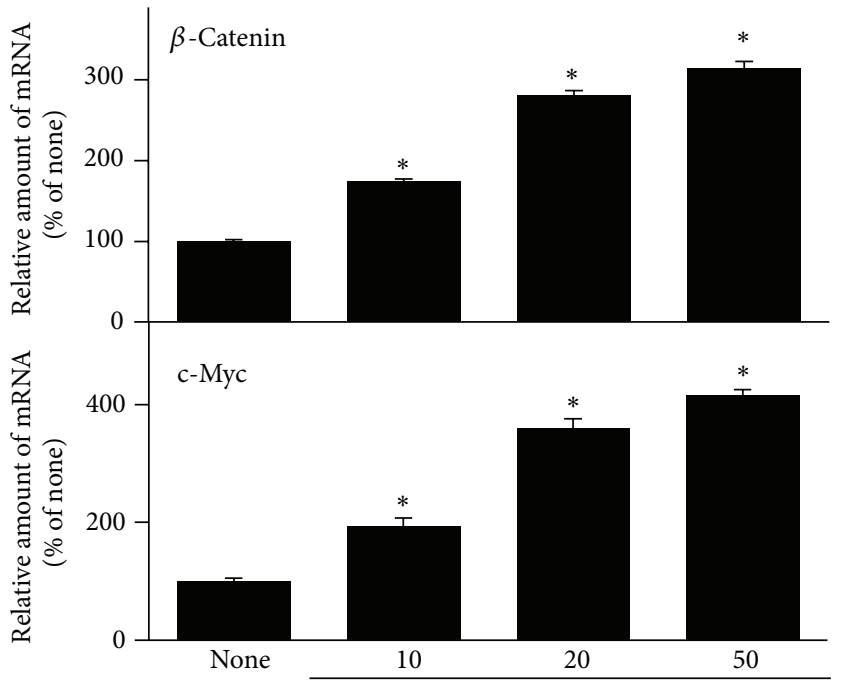

H. pylori/cells

(d)

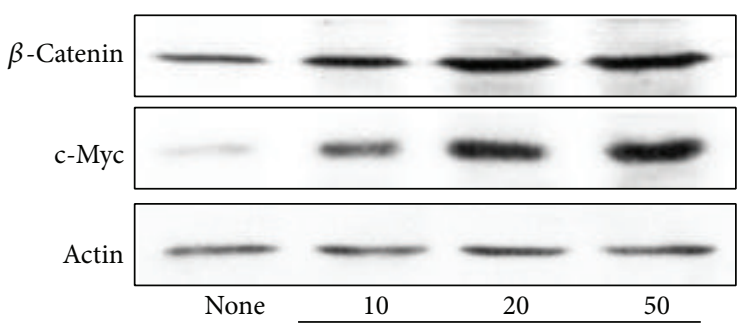

H. pylori/cells

(f)

FIGURE 2: ROS levels, NADPH oxidase activity, and mRNA and protein levels of $\beta$-catenin and c-myc in AGS cells infected with $H$. pylori. $(a, b, d, f)$ The cells were cultured in the presence or absence of H. pylori (at bacterium/cell ratio of 10, 20, 50:1) for 24 h. (c, e) AGS cells were cultured in the presence or absence of H. pylori (bacterium/cell ratio of $50: 1$ ) for the indicated time period. (a) ROS levels were determined by DCF fluorescence after $30 \mathrm{~min}$ of $H$. pylori infection. The levels of ROS trapped in the cells and cultured in the absence of $H$. pylori (none) are considered as $100 \%$. (b) NADPH oxidase activity was determined by lucigenin assay using membrane extracts of the cells. NADPH oxidase activity was also monitored by addition of cytosolic extracts to the reaction mixture as a negative control. (c-f) mRNA and protein expression were determined by real-time PCR and Western blot analysis, respectively. Actin served as a loading control. ${ }^{*} \mathrm{P}<0.05$ versus $0 \mathrm{~h}$ or none (the cells cultured in the absence of $H$. pylori). 


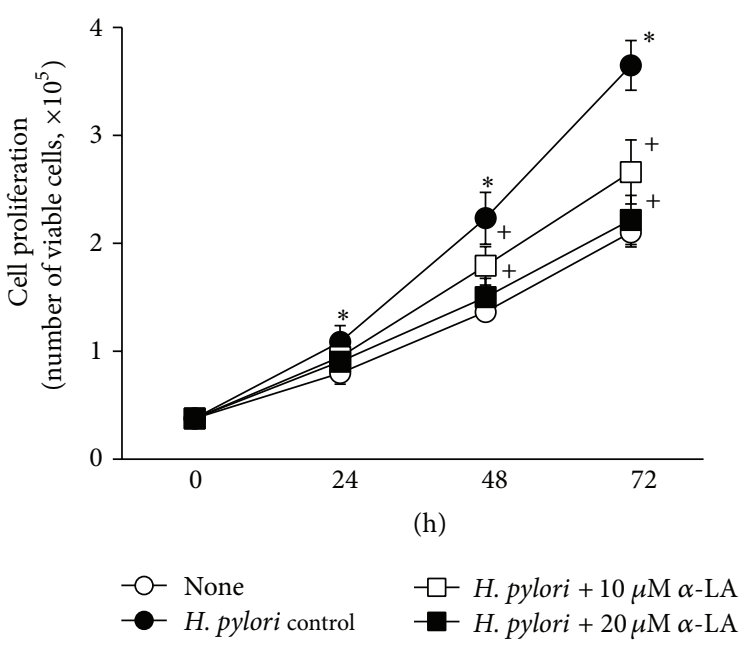

(a)

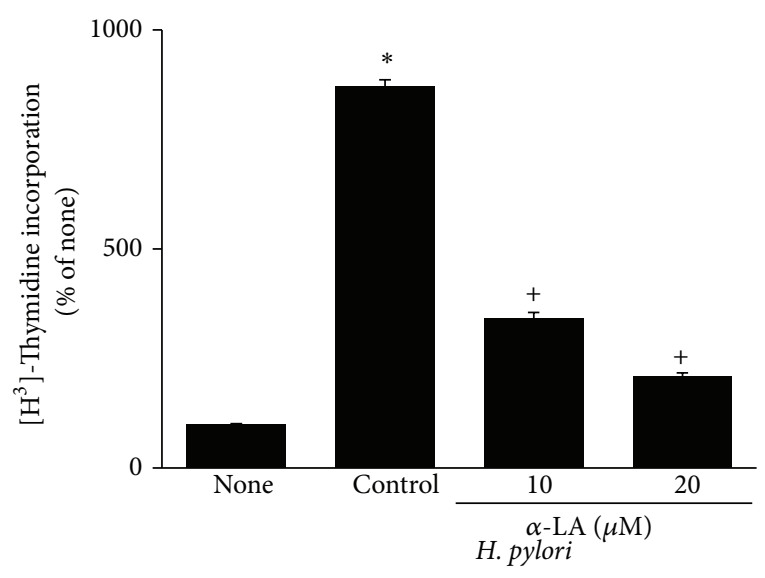

(b)

FIGURE 3: Effect of $\alpha$-LA on cell proliferation of $H$. pylori-infected AGS cells. The cells were pretreated with $\alpha$-LA for $2 \mathrm{~h}$ and cultured in the presence or absence of $H$. pylori. Cell proliferation was assessed by viable cell numbers and $\left[{ }^{3} \mathrm{H}\right]$ thymidine incorporation. (a) Viable cell numbers were determined by trypan blue exclusion assay for the indicated time period. (b) The cells were treated with $\left[{ }^{3} \mathrm{H}\right]$ thymidine at $24 \mathrm{~h}$ after $H$. pylori infection and incubated for $8 \mathrm{~h}$. The amount of $\left[{ }^{3} \mathrm{H}\right]$ thymidine incorporation of AGS cells cultured in the absence of $H$. pylori is considered as $100 \% .{ }^{*} P<0.05$ versus corresponding none (the cells cultured in the absence of $H$. pylori); ${ }^{+} P<0.05$ versus corresponding H. pylori control (the cells cultured in the presence of $H$. pylori and treated without $\alpha$-LA).

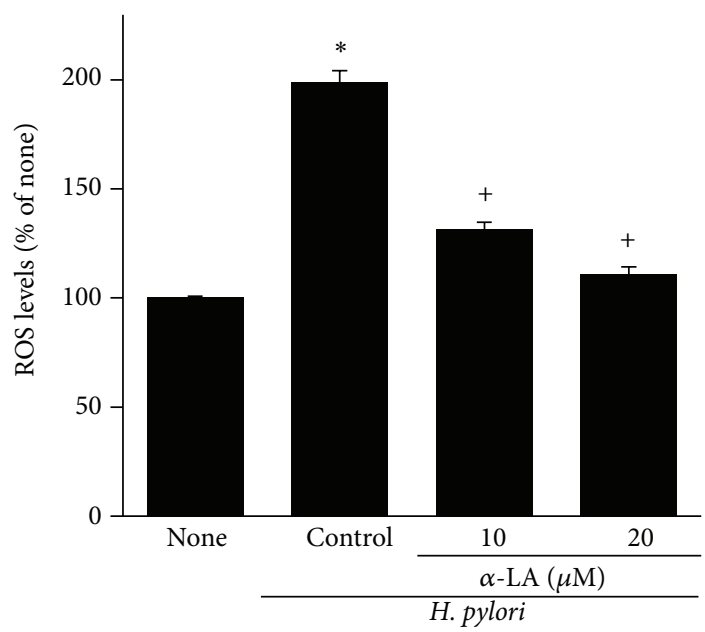

(a)

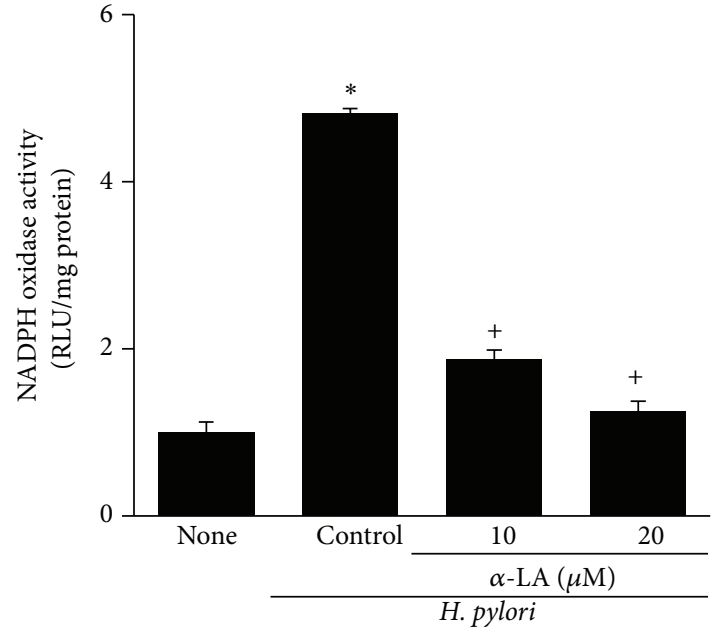

(b)

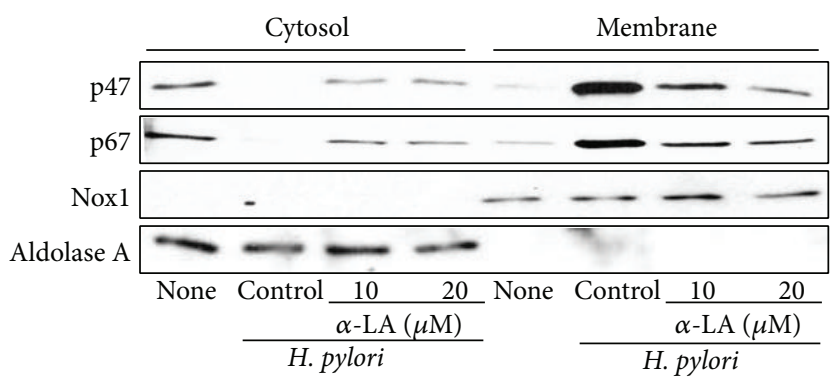

(c)

FIGURE 4: Effect of $\alpha$-LA on ROS levels, NADPH oxidase activity, and levels of NADPH oxidase subunits in $H$. pylori-infected AGS cells. The cells were pretreated with $\alpha$-LA for $2 \mathrm{~h}$ and cultured in the presence or absence of $H$. pylori. (a) ROS levels were determined by DCF fluorescence after $30 \mathrm{~min}$ of $\mathrm{H}$. pylori infection. The levels of ROS trapped in the cells treated without DPI and cultured in the absence of H. pylori are considered as $100 \%$. (b) NADPH oxidase activity was determined by lucigenin assay using membrane extracts of the cells. NADPH oxidase activity was also monitored by addition of cytosolic extracts to the reaction mixture as a negative control. (c), Protein levels of NADPH oxidase subunits (p47, p67) in cytosolic and membrane extracts were determined by Western blotting. Aldolase A and Nox1 were used as indices for cytosol and membrane, respectively. ${ }^{*} P<0.05$ versus none (the cells cultured in the absence of $H$. pylori); ${ }^{+} P<0.05$ versus control (the cells cultured in the presence of $H$. pylori and treated without $\alpha$-LA). 


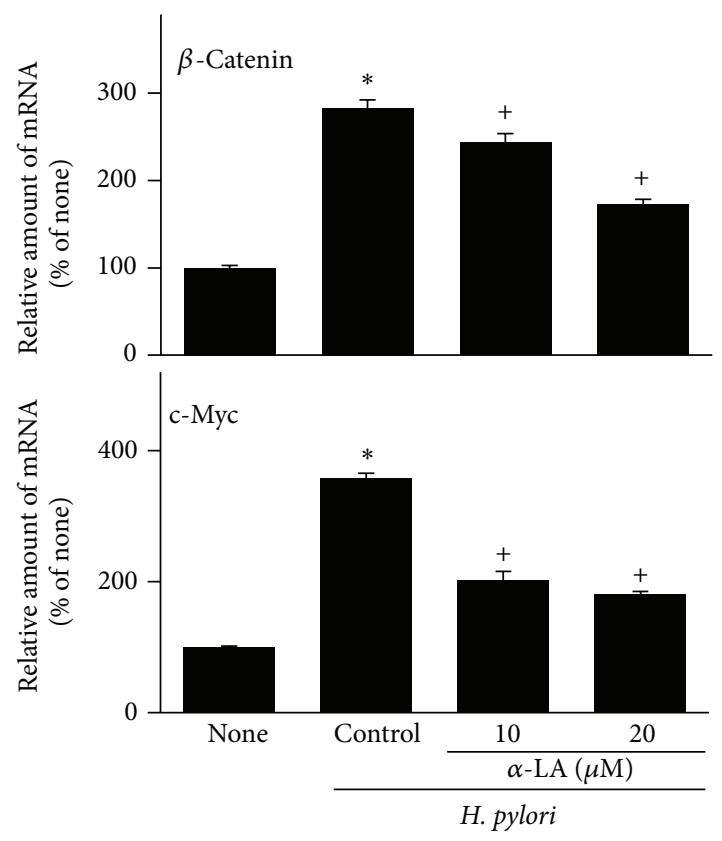

(a)

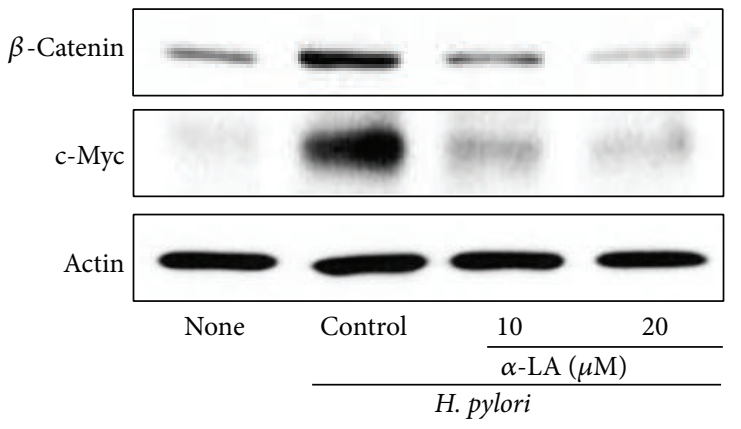

(b)
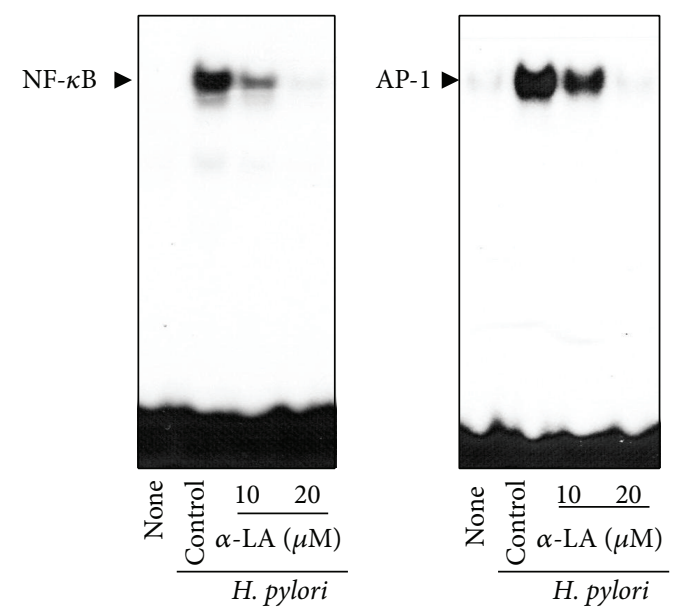

(c)

FIGURE 5: Effect of $\alpha$-LA on expression of $\beta$-catenin and c-myc as well as activation of NF- $\kappa \mathrm{B}$ and AP-1 in $H$. pylori-infected AGS cells. The cells were pretreated with $\alpha$-LA for $2 \mathrm{~h}$ and cultured in the presence or absence of $H$. pylori for $24 \mathrm{~h}$ (mRNA, protein levels) or $1 \mathrm{~h}$ (activation of NF- $\kappa$ B and AP-1). (a) mRNA expression of $\beta$-catenin and c-myc was measured by real-time PCR analysis. (b) Protein levels of $\beta$-catenin and c-myc were determined by Western blot analysis. Actin served as a loading control. (c) EMSA was performed for DNA binding activities of NF- $\kappa$ B and AP-1. ${ }^{*} P<0.05$ versus none (the cells cultured in the absence of $H$. pylori); ${ }^{+} P<0.05$ versus control (the cells cultured in the presence of $H$. pylori and treated without $\alpha$-LA).

of DPI on H. pylori-induced ROS production, hyperproliferation, oncogene expression, and activation of NF- $\kappa \mathrm{B}$ and AP-1 was higher at $2 \mu \mathrm{M}$ than $1 \mu \mathrm{M}$ of DPI.

\section{Discussion}

The present study demonstrates that $H$. pylori-induced hyperproliferation and expression of oncogenes ( $\beta$-catenin, cmyc) are mediated with NADPH oxidase-generated ROS and activation of redox-sensitive transcription factors (NF$\kappa \mathrm{B}, \mathrm{AP}-1)$ in $H$. pylori-infected cells. Evidence for NADPH oxidase generation of ROS during cell proliferation came from the current findings that the cell proliferation and oncogene expression were decreased by an NADPH oxidase inhibitor DPI in $H$. pylori-infected AGS cells. Since $\alpha$-LA suppresses NADPH oxidase activation and ROS production in $H$. pylori-infected gastric epithelial cells, $\alpha$-LA may prevent early gastric carcinogenesis associated with $H$. pylori infection, by inhibiting activation of NF- $\kappa \mathrm{B}$ and AP-1, expression of $\beta$-catenin and c-myc, and hyperproliferation of gastric epithelial cells.

Present result is supported by the previous study showing that $\alpha$-LA attenuated ROS production and NADPH oxidase activities in the kidneys of diabetic rats [34]. Therefore, 


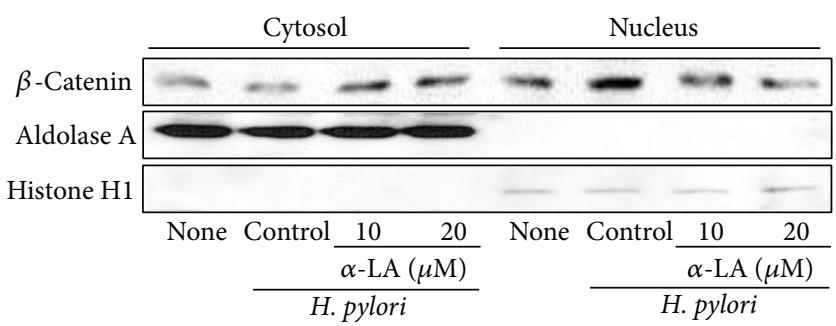

(a)

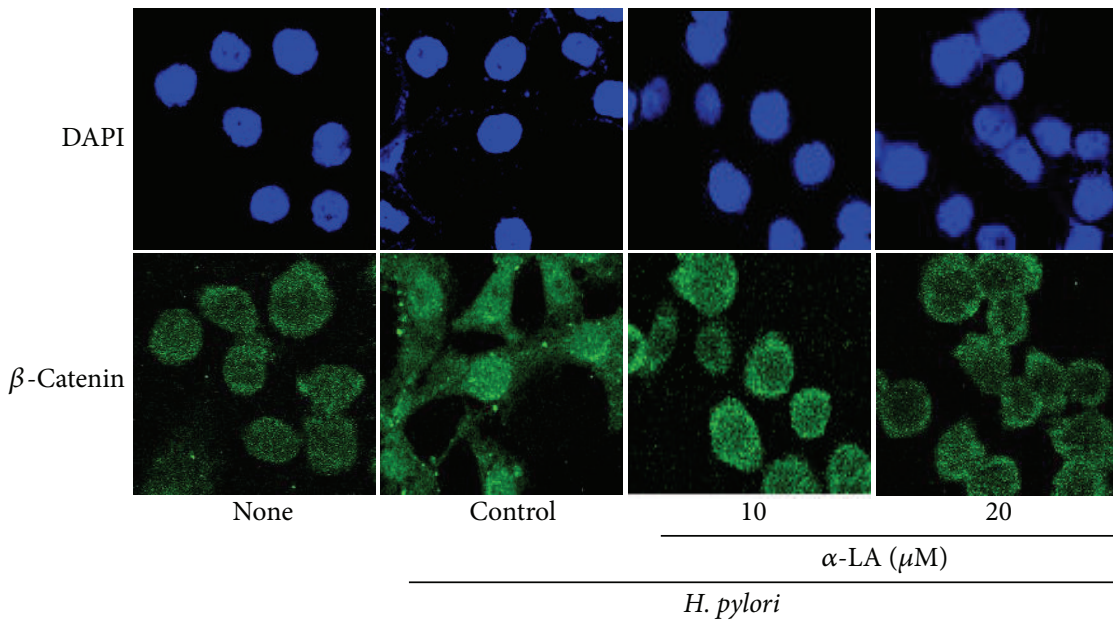

(b)

FIGURE 6: Effect of $\alpha$-LA on activation of $\beta$-catenin in $H$. pylori-infected AGS cells. AGS cells were pretreated with $\alpha$-LA for $2 \mathrm{~h}$ and cultured in the presence or absence of $H$. pylori for $24 \mathrm{~h}$. (a) Protein levels of $\beta$-catenin in cytosolic and nuclear extracts were determined by Western blot analysis. Aldolase A and histone $\mathrm{H} 1$ were used as indices for cytosolic and nuclear extracts, respectively. (b) Immunofluorescence staining was performed to determine the levels of $\beta$-catenin in nucleus and cytosol. $\beta$-catenin was visualized using fluorescein isothiocyanate-conjugated anti-mouse IgG antibody (lower panel) with DAPI counter staining (upper panel) of the same field.

inhibition of NADPH oxidase activation may contribute to beneficial effect of $\alpha$-LA for treatment of oxidative stressmediated diseases including $H$. pylori-associated gastric cancer.

$\alpha$-LA serves as an essential cofactor for mitochondrial enzymes involved in metabolism and energy production [30]. $\alpha$-LA is a powerful antioxidant that quenches various intracellular ROS [35]. Thus, $\alpha$-LA has been introduced to prevent or treat oxidative stress-associated diseases, such as diabetes [36, 37], ischemia-reperfusion injury [38, 39], fibrosis [40, 41], and neurodegenerative processes [42, 43].

In regard to anticancer effect of $\alpha$-LA, $\alpha$-LA prevented p53 degradation in colon cancer cells by inhibiting NF$\kappa \mathrm{B}$ activation [44]. Anticancer effect of $\alpha$-LA on non-small cell lung cancer cells was associated with an inhibition in the cell-cycle transition from the G1 phase to the $S$ phase without inducing apoptosis [45]. In addition, $\alpha$-LA inhibited migration and invasion by downregulation of cell surface $\beta 1$-integrin expression in bladder cancer cells [46]. Present findings demonstrate that anticancer mechanism of $\alpha$-LA is inhibition of NADPH oxidase which is upstream signaling for activation of redox-sensitive transcription factors, expression of oncogenes, nuclear translocation of $\beta$-catenin, and, finally, hyperproliferation of $H$. pylori-infected gastric epithelial cells.

Bandapalli et al. [47] reported that overexpression of $\beta$ catenin increases nuclear level of $\beta$-catenin and carcinogenesis including metastasis. As mentioned previously, $\beta$-catenin expression may be regulated by $\mathrm{NF}-\kappa \mathrm{B}$ and $\mathrm{AP}-1[21,22]$. Therefore, $H$. pylori infection may induce expression and activation of $\beta$-catenin by activating NF- $\kappa$ B and AP-1 in gastric epithelial cells.

$H$. pylori strains that express the cagA and vacA genes are associated with development of chronic gastritis and intestinal metaplasia as well as increased risk for gastric cancer $[48,49]$. H. pylori has shown that approximately $50-60 \%$ of strains have a $40 \mathrm{~kb}$ DNA segment called the cytotoxin-associated gene (cagA) pathogenecity island (PAI) [50]. Some of the proteins encoded by cagA PAI genes are responsible for oxidant-sensitive transcription factor $\mathrm{NF}-\kappa \mathrm{B}$ in gastric epithelial cells [51], which may contribute to the development of peptic ulceration, atrophic gastritis, and gastric carcinoma [52, 53]. Intestinal type gastric carcinoma is associated with high expression of c-myc through $\mathrm{NF}-\kappa \mathrm{B} / \mathrm{p} 65$ activated by $H$. Pylori cagA [54] H. pylori cagA mediates mitogenic signal through 


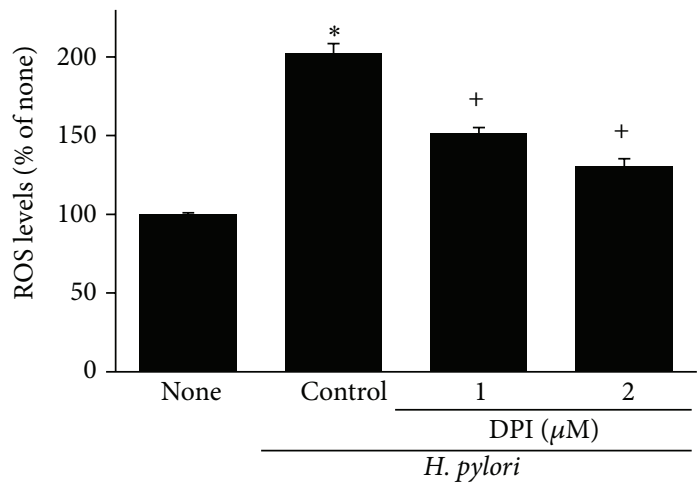

(a)

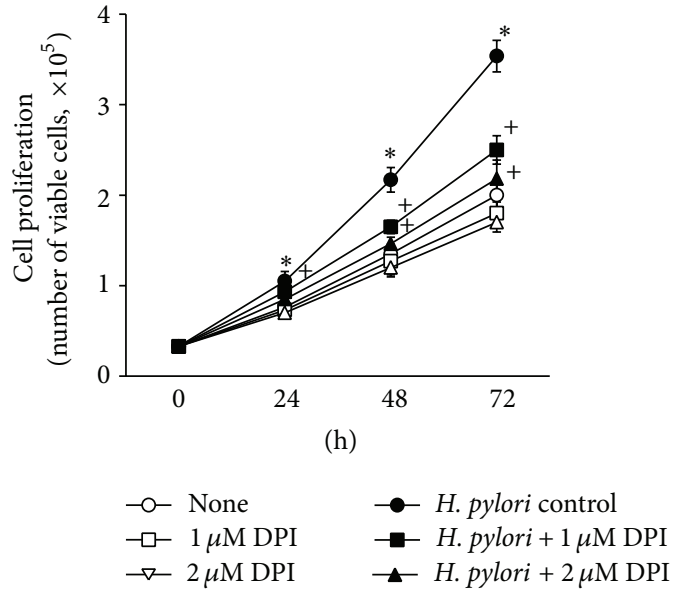

(b)

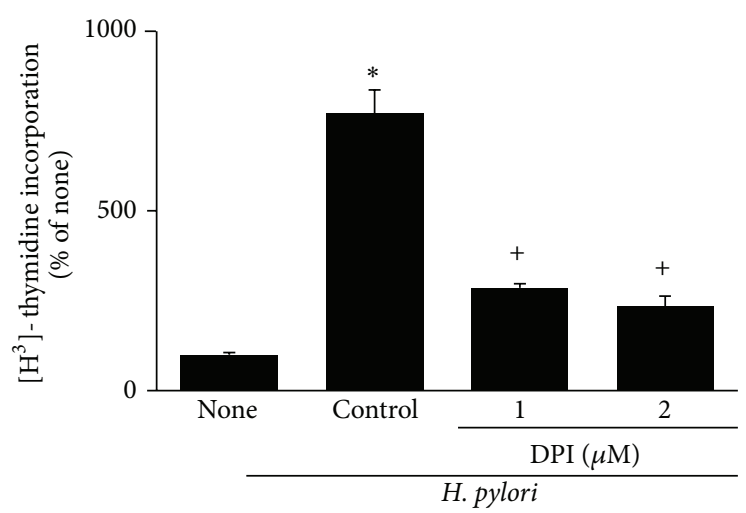

(c)

FIGURE 7: Effect of DPI on ROS levels and cell proliferation of $H$. pylori-infected AGS cells. The cells were pretreated with DPI for $2 \mathrm{~h}$ and cultured in the presence or absence of $H$. pylori. (a) ROS levels were determined by DCF fluorescence after $30 \mathrm{~min}$ of $H$. pylori infection. The levels of ROS trapped in the cells treated without DPI and cultured in the absence of H. pylori are considered as $100 \%$. (b) Viable cell numbers were determined by trypan blue exclusion assay for the indicated time period. (c) The cells were treated with $\left[{ }^{3} \mathrm{H}\right]$ thymidine at $24 \mathrm{~h}$ after H. pylori infection and incubated for $8 \mathrm{~h}$. The amount of $\left[{ }^{3} \mathrm{H}\right]$ thymidine incorporation of AGS cells cultured in the absence of $H$. pylori is considered as $100 \%$. ${ }^{*} \mathrm{P}<0.05$ versus corresponding none (the cells cultured in the absence of $H$. pylori); ${ }^{+} \mathrm{P}<0.05$ versus corresponding $H$. pylori control (the cells cultured in the presence of $H$. pylori and treated without DPI).

Src homology 2 (SH2) domain-containing protein-tyrosine phosphatase-2 (SHP-2) activation in the infected cells [55]. In addition, $H$. pylori vacA upregulates chemokine expression in human eosinophils via $\mathrm{Ca}^{2+}$ influx, mitochondrial ROS, and NF- $\kappa \mathrm{B}$ activation [56]. H. pylori used in the study has virulence-associated genes such as vacA and cagA $[57,58]$. There have been no studies on the direct effect of $\alpha$-LA on virulence factors cagA and vacA. The present findings suggest that both cagA and vacA may contribute to the activation of NADPH oxidase, hyperproliferation, and oncogene expression in $H$. pylori- infected cells.

In the present study, $\alpha$-LA suppressed $H$. pylori-induced activation of NADPH oxidase, ROS production, and redoxsensitive transcription factors NF- $\kappa \mathrm{B}$ and AP-1 in AGS cells. Since we found that expression of $\beta$-catenin and $c$-myc is regulated by $\mathrm{NF}-\kappa \mathrm{B}$ and $\mathrm{AP}-1$, inhibitory effect of $\alpha$-LA on expression of $\beta$-catenin and $c$-myc and hyperproliferation may be related to suppression of NF- $\kappa$ B and AP- 1 in the infected cells. H. pylori-induced nuclear localization of $\beta$ catenin may induce expression of c-myc since $\beta$-catenin is reported to be shuttled into the nucleus and activate the transcription of target gene c-myc. Conclusively, $\alpha$-LA inhibits $H$. pylori-induced hyperproliferation since c-myc acts as an oncogenic transcription factor for target genes to stimulate uncontrolled cell proliferation.

\section{Conclusion}

$\alpha$-LA inhibits NADPH oxidase and, thus, suppresses ROS production which prevents oncogene expression, nuclear translocation of $\beta$-catenin, and hyperproliferation by regulating the activation of NF- $\kappa$ B and AP- 1 . $\alpha$-LA may be beneficial for prevention or therapeutic intervention for gastric carcinogenesis associated with $H$. pylori infection. 


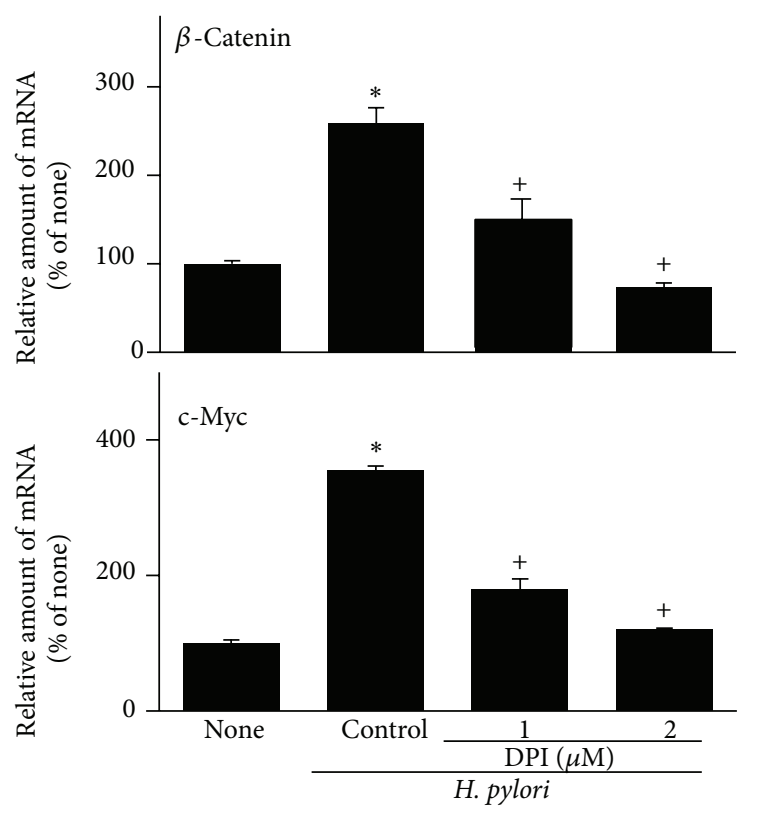

(a)
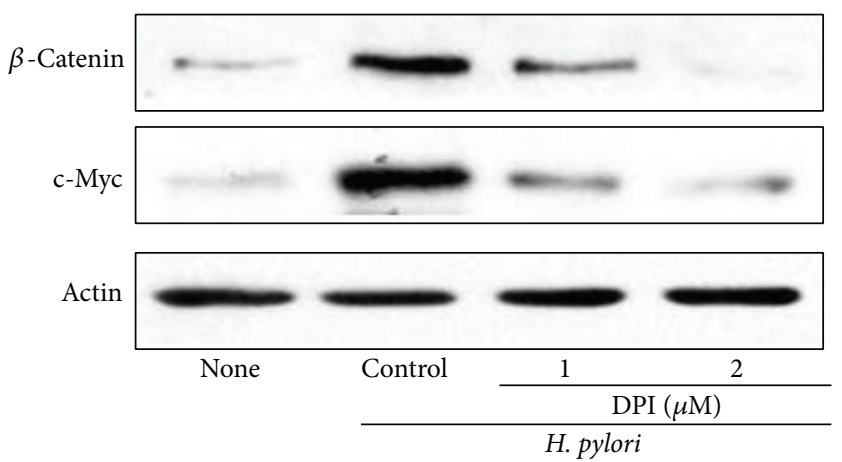

(b)
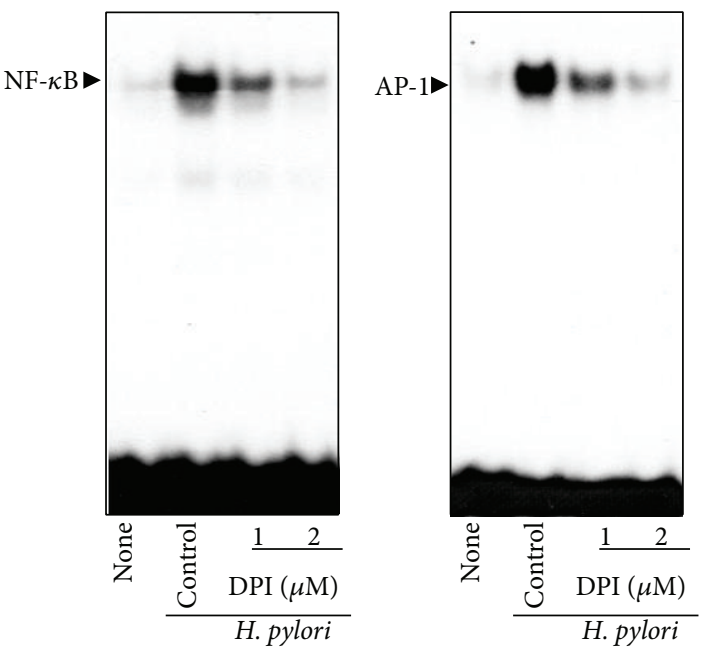

(c)

FIGURE 8: Effect of DPI on expression of $\beta$-catenin and c-myc as well as activation of NF- $\kappa \mathrm{B}$ and AP-1 in $H$. pylori-infected AGS cells. The cells were pretreated with DPI for $2 \mathrm{~h}$ and cultured in the presence or absence of $H$. pylori for $24 \mathrm{~h}$ (mRNA, protein levels) or $1 \mathrm{~h}$ (activation of NF- $\kappa$ B and AP-1). (a) mRNA expression of $\beta$-catenin and c-myc was measured by real-time PCR analysis. (b) Protein levels of $\beta$-catenin and c-myc were determined by Western blot analysis. Actin served as a loading control. (c), EMSA was performed for DNA binding activities of NF- $\kappa$ B and AP-1. ${ }^{*} P<0.05$ versus corresponding none (the cells cultured in the absence of $H$. pylori); ${ }^{+} P<0.05$ versus corresponding $H$. pylori control (the cells cultured in the presence of $H$. pylori and treated without DPI).

\section{Conflict of Interests}

The authors declare that there is no conflict of interests regarding the publication of this paper.

\section{Acknowledgments}

This work was supported by Grants from the NRF of Korea funded by the Korean Government (MSIP) (2007-0056092 and NRF-2012R1A1A2043423).

\section{References}

[1] D. Forman, D. G. Newel, F. Fullerton et al., "Association between infection with Helicobacter pylori and risk of gastric cancer: evidence from a prospective investigation," British Medical Journal, vol. 302, no. 6788, pp. 1302-1305, 1991.

[2] J. Parsonnet, G. D. Friedman, D. P. Vandersteen et al., "Helicobacter pylori infection and the risk of gastric carcinoma," The New England Journal of Medicine, vol. 325, no. 16, pp. 1127-1131, 1991. 
[3] A. Nomura, G. N. Stemmermann, P. Chyou, I. Kato, G. I. Perez-Perez, and M. J. Blaser, "Helicobacter pylori infection and gastric carcinoma among Japanese Americans in Hawaii," The New England Journal of Medicine, vol. 325, no. 16, pp. 1132-1136, 1991.

[4] N. Uemura, S. Okamoto, S. Yamamoto et al., "Helicobacter pylori infection and the development of gastric cancer," The New England Journal of Medicine, vol. 345, no. 11, pp. 784-789, 2001.

[5] N. L. Jones, P. T. Shannon, E. Cutz, H. Yeger, and P. M. Sherman, "Increase in proliferation and apoptosis of gastric epithelial cells early in the natural history of Helicobacter pylori infection," The American Journal of Pathology, vol. 151, no. 6, pp. 1695-1703, 1997.

[6] T. A. Nagy, L. E. Wroblewski, D. Wang et al., " $\beta$-catenin and p120 mediate PPAR $\delta$-dependent proliferation induced by helicobacter pylori in human and rodent epithelia," Gastroenterology, vol. 141, no. 2, pp. 553-564, 2011.

[7] T. Gnad, M. Feoktistova, M. Leverkus, U. Lendeckel, and M. Naumann, "Helicobacter pylori-induced activation of $\beta$-catenin involves low density lipoprotein receptor-related protein 6 and Dishevelled," Molecular Cancer, vol. 9, article 31, 2010.

[8] H. Clevers and R. Nusse, "Wnt/ $\beta$-catenin signaling and disease," Cell, vol. 149, no. 6, pp. 1192-1205, 2012.

[9] C. Y. Logan and R. Nusse, "The Wnt signaling pathway in development and disease," Annual Review of Cell and Developmental Biology, vol. 20, no. 1, pp. 781-810, 2004.

[10] N. Barker, P. J. Morin, and H. Clevers, "The Yin-Yang of TCF/ $\beta$ catenin signaling," Advances in Cancer Research, vol. 77, pp. 1$24,2000$.

[11] J. Behrens, B. Jerchow, M. Würtele et al., "Functional interaction of an axin homolog, conductin, with $\beta$-catenin, APC, and GSK3 3," Science, vol. 280, no. 5363, pp. 596-599, 1998.

[12] R. J. MacLeod, "MDR-1, Bcl-xL, H. pylori, and Wnt/ $\beta$-catenin signalling in the adult stomach: how much is too much?" Laboratory Investigation, vol. 92, no. 12, pp. 1670-1673, 2012.

[13] S. W. A. Himaya, P. Dewapriya, and S. Kim, "EGFR tyrosine kinase inhibitory peptide attenuates Helicobacter pylorimediated hyper-proliferation in AGS enteric epithelial cells," Toxicology and Applied Pharmacology, vol. 269, no. 3, pp. 205214, 2013.

[14] I. M. Shih, J. Yu, T. C. He, B. Vogelstein, and K. W. Kinzler, "The $\beta$-catenin binding domain of adenomatous polyposis coli is sufficient for tumor suppression," Cancer Research, vol. 60, no. 6, pp. 1671-1676, 2000.

[15] C. V. Dang, "c-Myc target genes involved in cell growth, apoptosis, and metabolism," Molecular and Cellular Biology, vol. 19, no. 1, pp. 1-11, 1999.

[16] J. H. Seo, J. W. Lim, H. Kim, and K. H. Kim, “Helicobacter pylori in a Korean isolate activates mitogen-activated protein kinases, $\mathrm{AP}-1$, and NF- $\kappa \mathrm{B}$ and induces chemokine expression in gastric epithelial AGS cells," Laboratory Investigation, vol. 84, no. 1, pp. 49-62, 2004.

[17] J. I. Keenan, R. A. Peterson II, and M. B. Hampton, "NADPH oxidase involvement in the pathology of Helicobacter pylori infection," Free Radical Biology and Medicine, vol. 38, no. 9, pp. 1188-1196, 2005.

[18] K. Tominaga, T. Kawahara, T. Sano et al., "Evidence for cancerassociated expression of NADPH oxidase 1 (Noxl)-based oxidase system in the human stomach," Free Radical Biology and Medicine, vol. 43, no. 12, pp. 1627-1638, 2007.
[19] B. Cha, J. W. Lim, K. H. Kim, and H. Kim, "15-deoxy- $\Delta 12,14-$ prostaglandin $\mathrm{j} 2$ suppresses rantes expression by inhibiting nadph oxidase activation in helicobacter pylori-infected gastric epithelial cells," Journal of Physiology and Pharmacology, vol. 62, no. 2, pp. 167-174, 2011.

[20] B. M. Babior, J. D. Lambeth, and W. Nauseef, "The neutrophil NADPH oxidase," Archives of Biochemistry and Biophysics, vol. 397, no. 2, pp. 342-344, 2002.

[21] F. Nollet, G. Berx, F. Molemans, and F. Van Roy, "Genomic organization of the human $\beta$-catenin gene (CTNNB1)," Genomics, vol. 32, no. 3, pp. 413-424, 1996.

[22] F. Götschel, C. Kern, S. Lang et al., "Inhibition of GSK3 differentially modulates NF- $\kappa \mathrm{B}, \mathrm{CREB}, \mathrm{AP}-1$ and $\beta$-catenin signaling in hepatocytes, but fails to promote TNF- $\alpha$-induced apoptosis," Experimental Cell Research, vol. 314, no. 6, pp. 13511366, 2008

[23] L. J. Reed, "A trail of research from lipoic acid to alpha- keto acid dehydrogenase complexes," The Journal of Biological Chemistry, vol. 276, no. 42, pp. 38329-38336, 2001.

[24] A. Bast and G. R. M. M. Haenen, "Interplay between lipoic acid and glutathione in the protection against microsomal lipid peroxidation," Biochimica et Biophysica Acta, vol. 963, no. 3, pp. 558-561, 1988.

[25] L. Packer, " $\alpha$-Lipoic acid: a metabolic antioxidant which regulates NF- $\kappa \mathrm{B}$ signal transduction and protects against oxidative injury," Drug Metabolism Reviews, vol. 30, no. 2, pp. 245-275, 1998.

[26] E. Vig-Varga, E. A. Benson, T. L. Limbil, B. M. Allison, M. G. Goebl, and M. A. Harrington, "Alpha-lipoic acid modulates ovarian surface epithelial cell growth," Gynecologic Oncology, vol. 103, no. 1, pp. 45-52, 2006.

[27] U. Wenzel, A. Nickel, and H. Daniel, " $\alpha$-lipoic acid induces apoptosis in human colon cancer cells by increasing mitochondrial respiration with a concomitant $\mathrm{O}_{2}{ }^{-}$-generation," Apoptosis, vol. 10, no. 2, pp. 359-368, 2005.

[28] S. E. Lee, J. W. Lim, J. M. Kim, and H. Kim, "Anti-inflammatory mechanism of polyunsaturated fatty acids in Helicobacter pylori-infected gastric epithelial cells," Mediators of Inflammation, vol. 2014, Article ID 128919, 12 pages, 2014.

[29] J. W. Lim, H. Kim, and K. H. Kim, "Nuclear factor- $\kappa$ B regulates cyclooxyoenase-2 expression and cell proliferation in human gastric cancer cells," Laboratory Investigation, vol. 81, no. 3, pp. 349-360, 2001.

[30] A. Goraç, H. Huk-Kolega, A. Piechota, P. Kleniewska, E. Ciejka, and B. Skibska, "Lipoic acid-biological activity and therapeutic potential," Pharmacological Reports, vol. 63, no. 4, pp. 849-858, 2011.

[31] S. H. Jang, J. W. Lim, T. Morio, and H. Kim, "Lycopene inhibits Helicobacter pylori-induced ATM/ATR-dependent DNA damage response in gastric epithelial AGS cells," Free Radical Biology and Medicine, vol. 52, no. 3, pp. 607-615, 2012.

[32] J. H. Yu, K. H. Kim, D. G. Kim, and H. Kim, "Diphenyleneiodonium suppresses apoptosis in cerulein-stimulated pancreatic acinar cells," International Journal of Biochemistry and Cell Biology, vol. 39, no. 11, pp. 2063-2075, 2007.

[33] D. J. Mulholland, H. Cheng, K. Reid, P. S. Rennie, and C. C. Nelson, "The androgen receptor can promote $\beta$-catenin nuclear translocation independently of adenomatous polyposis coli," The Journal of Biological Chemistry, vol. 277, no. 20, pp. 1793317943, 2002.

[34] F. Bhatti, R. W. Mankhey, L. Asico, M. T. Quinn, W. J. Welch, and C. Maric, "Mechanisms of antioxidant and pro-oxidant effects 
of $\alpha$-lipoic acid in the diabetic and nondiabetic kidney," Kidney International, vol. 67, no. 4, pp. 1371-1380, 2005.

[35] A. Bilska and L. Włodek, "Lipoic acid-the drug of the future?" Pharmacological Reports, vol. 57, no. 5, pp. 570-577, 2005.

[36] J. Arambašić, M. Mihailović, A. Uskoković et al., "Alphalipoic acid upregulates antioxidant enzyme gene expression and enzymatic activity in diabetic rat kidneys through an $\mathrm{O}-$ GlcNAc-dependent mechanism," European Journal of Nutrition, vol. 52, no. 5, pp. 1461-1473, 2013.

[37] L. Wang, C. G. Wu, C. Q. Fang et al., "The protective effect of $\alpha$-lipoic acid on mitochondria in the kidney of diabetic rats," International Journal of Clinical and Experimental Medicine, vol. 6, no. 2, pp. 90-97, 2013.

[38] L. He, B. Liu, Z. Dai et al., "Alpha lipoic acid protects heart against myocardial ischemia-reperfusion injury through a mechanism involving aldehyde dehydrogenase 2 activation," European Journal of Pharmacology, vol. 678, no. 1-3, pp. 32-38, 2012.

[39] C. Deng, Z. Sun, G. Tong et al., " $\alpha$-Lipoic acid reduces infarct size and preserves cardiac function in rat myocardial ischemia/reperfusion injury through activation of PI3K/ Akt /Nrf2 pathway," PLoS ONE, vol. 8, no. 3, Article ID e58371, 2013.

[40] M. Kaya, C. H. Yildirim, K. Kosemehmetoglu et al., "Alphalipoic acid reduces peridural fibrosis after laminectomy of lumbar vertebrae in rabbits," Acta Neurochirurgica, vol. 154, no. 7, pp. 1241-1245, 2012.

[41] J. E. Lee, C. Yi, B. T. Jeon et al., "Alpha-lipoic acid attenuates cardiac fibrosis in Otsuka Long-Evans Tokushima Fatty rats," Cardiovascular Diabetology, vol. 11, article 111, 2012.

[42] S. A. Farr, T. O. Price, W. A. Banks, N. Ercal, and J. E. Morley, "Effect of alpha-lipoic acid on memory, oxidation, and lifespan in SAMP8 mice," Journal of Alzheimer's Disease, vol. 32, no. 2, pp. 447-455, 2012.

[43] B. Liu, X. Ma, D. Guo, Y. Guo, N. Chen, and H. Bi, "Neuroprotective effect of $\alpha$-lipoic acid on hydrostatic pressure-induced damage of retinal ganglion cells in vitro," Neuroscience Letters, vol. 526, no. 1, pp. 24-28, 2012.

[44] T. Yoo, J. Lee, H. Chun, and S. Chi, “ $\alpha$-Lipoic acid prevents p53 degradation in colon cancer cells by blocking NF- $\kappa$ B induction of RPS6KA4," Anti-Cancer Drugs, vol. 24, no. 6, pp. 555-565, 2013.

[45] H. Michikoshi, T. Nakamura, K. Sakai et al., " $\alpha$-Lipoic acidinduced inhibition of proliferation and met phosphorylation in human non-small cell lung cancer cells," Cancer Letters, vol. 335, no. 2, pp. 472-478, 2013.

[46] M. Yamasaki, M. Iwase, K. Kawano et al., “ $\alpha$-Lipoic acid suppresses migration and invasion via downregulation of cell surface $\beta 1$-integrin expression in bladder cancer cells," Journal of Clinical Biochemistry and Nutrition, vol. 54, no. 1, pp. 18-25, 2014.

[47] O. R. Bandapalli, S. Dihlmann, R. Helwa et al., "Transcriptional activation of the $\beta$-catenin gene at the invasion front of colorectal liver metastases," Journal of Pathology, vol. 218, no. 3, pp. 370-379, 2009.

[48] M. R. Ki, M. Hwang, A. Y. Kim et al., "Role of vacuolating cytotoxin VacA and cytotoxin -associated antigen CagA of Helicobacter pylori in the progression of gastric cancer," Molecular and Cellular Biochemistry, 2014.

[49] F. Aziz, X. Chen, X. Yang, and Q. Yan, "Prevalence and correlation with clinical diseases of Helicobacter pylori cagA and vacA genotype among gastric patients from Northeast China,"
BioMed Research International, vol. 2014, Article ID 142980, 7 pages, 2014.

[50] N. S. Akopyants, S. W. Clifton, D. Kersulyte et al., "Analyses of the cag pathogenicity island of Helicobacter pylori," Molecular Microbiology, vol. 28, no. 1, pp. 37-53, 1998.

[51] S. Keates, A. C. Keates, M. Warny, R. M. Peek Jr., P. G. Murray, and C. P. Kelly, "Differential activation of mitogen-activated protein kinases in AGS gastric epithelial cells by cag+ and cagHelicobacter pylori," Journal of Immunology, vol. 163, no. 10, pp. 5552-5559, 1999.

[52] E. J. Kuipers, G. I. Perez-Perez, S. G. M. Meuwissen, and M. J. Blaser, "Helicobacter pylori and atrophic gastritis: importance of the cagA status," Journal of the National Cancer Institute, vol. 87, no. 23, pp. 1777-1780, 1995.

[53] M. J. Blaser, G. I. Perez-Perez, H. Kleanthous et al., "Infection with Helicobacter pylori strains possessing cagA is associated with an increased risk of developing adenocarcinoma of the stomach," Cancer Research, vol. 55, no. 10, pp. 2111-2115, 1995.

[54] G. Yang, C. Deng, Y. Xiong, L. Gong, B. Wang, and J. Luo, "Expression of nuclear factor-kappa B and target genes in gastric precancerous lesions and adenocarcinoma: association with Helicobacter pylori cagA (+) infection," World Journal of Gastroenterology, vol. 10, no. 4, pp. 491-496, 2004.

[55] H. Higashi, R. Tsutsumi, S. Muto et al., "SHP-2 tyrosine phosphatase as an intracellular target of Helicobacter pylori CagA protein," Science, vol. 295, no. 5555, pp. 683-686, 2002.

[56] M. K. Jung, S. K. Joo, Y. L. Jin et al., "Vacuolating cytotoxin in Helicobacter pylori water-soluble proteins upregulates chemokine expression in human eosinophils via $\mathrm{Ca}^{2+}$ influx, mitochondrial reactive oxygen intermediates, and NF- $\kappa \mathrm{B}$ activation," Infection and Immunity, vol. 75, no. 7, pp. 3373-3381, 2007.

[57] A. Labigne and H. de Reuse, "Determinants of Helicobacter pylori pathogenicity," Infectious Agents and Disease, vol. 5, no. 4, pp. 191-202, 1996.

[58] H. L. Mobley, "Defining Helicobacter pylori as a pathogen: strain heterogeneity and virulence," The American Journal of Medicine, vol. 100, no. 5A, pp. 2S-9S, 1996. 


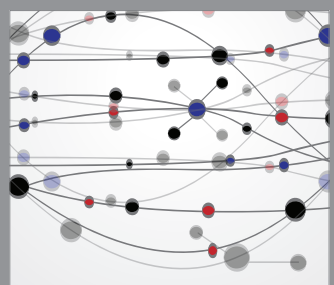

The Scientific World Journal
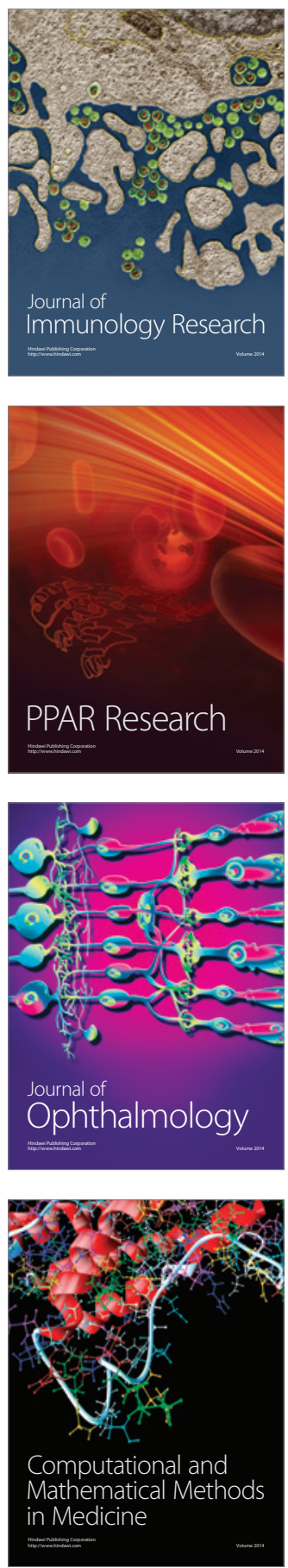

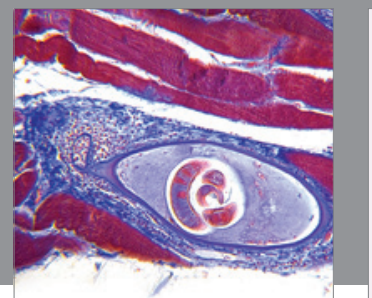

Gastroenterology

Research and Practice
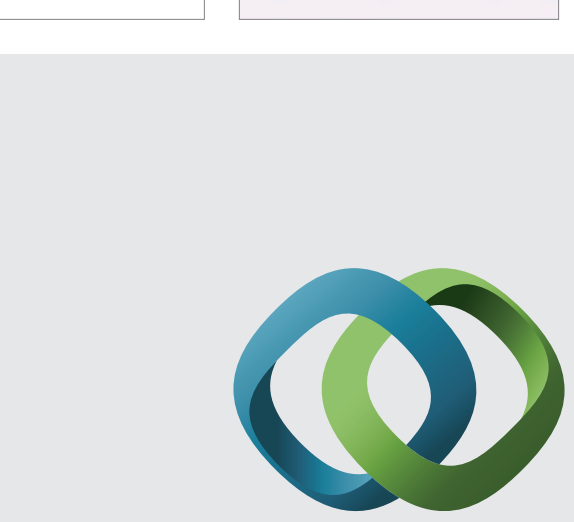

\section{Hindawi}

Submit your manuscripts at

http://www.hindawi.com
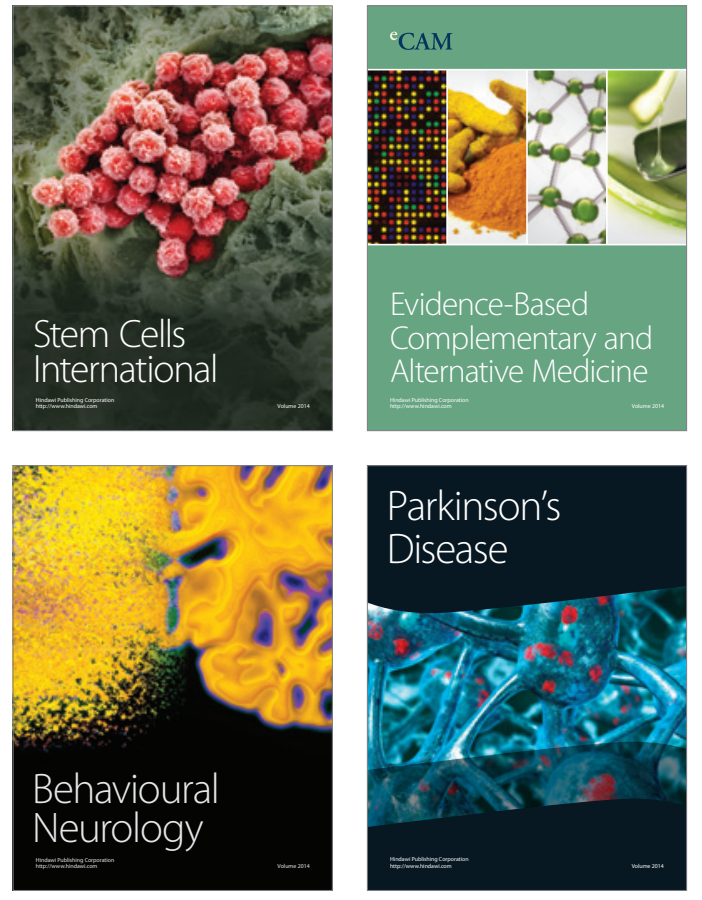
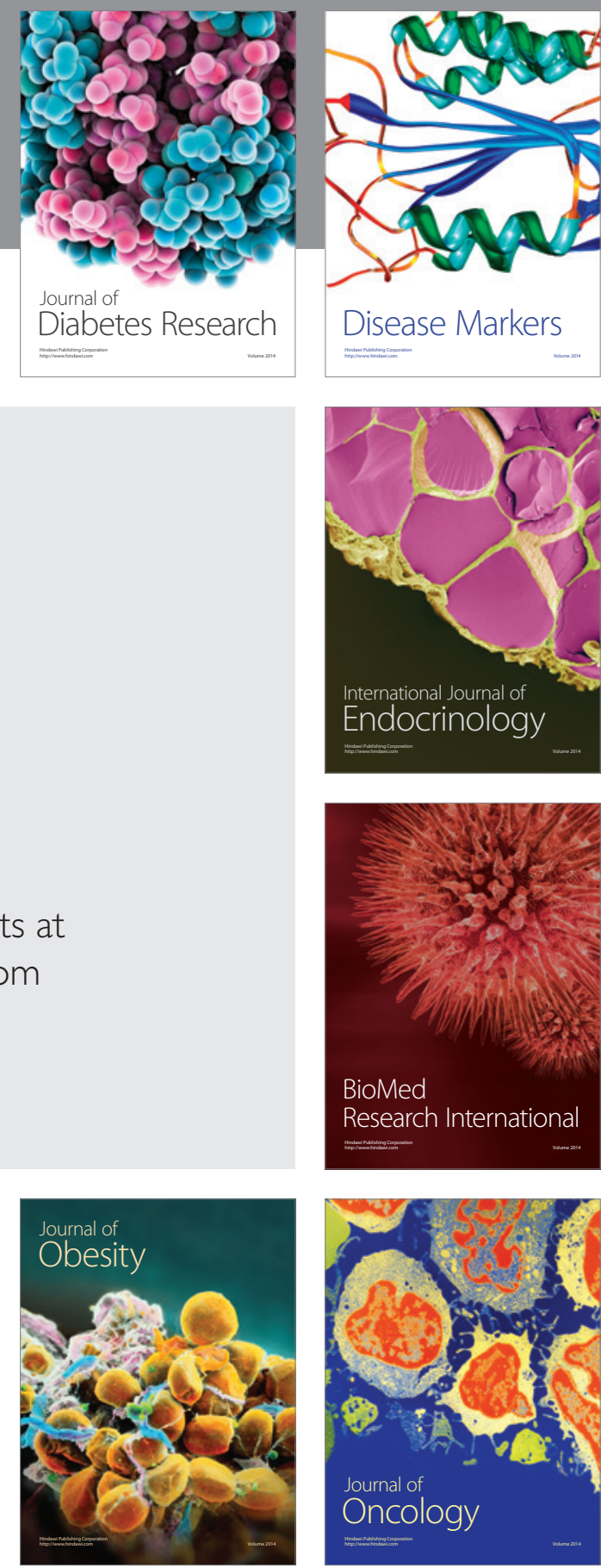

Disease Markers
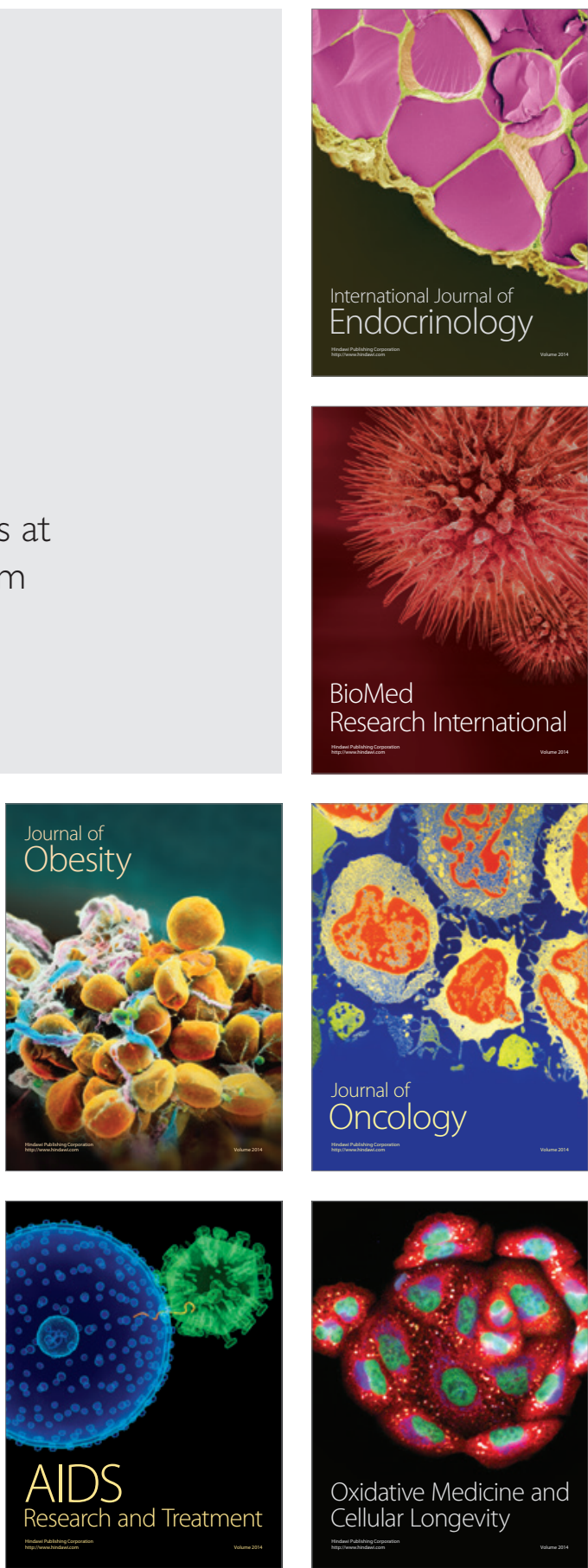